\title{
Hearing Foreigners' Voices: Unprecedented Communication for Hearing Foreigners' Voices in Saudi Arabia
}

\author{
Alaa Bakur ${ }^{1}$ \\ ${ }^{1}$ Phd., School of Communication and Media, king bdulaziz University, Jeddah, Saudi Arabia \\ Correspondence: Alaa Bakur, Phd., School of Communication and Media, king bdulaziz University, Jeddah, Saudi \\ Arabia.
}

Received: August 2, 2017

doi:10.11114/ijsss.v5i12.2747
Accepted: October 17,2017 Available online: October 31,2017

URL: https://doi.org/10.11114/ijsss.v5i12.2747

\begin{abstract}
After the Arab Spring uprisings, specifically the events in 2012, the Saudi Arabian Ministry of Labor inaugurated a participatory management department to engage with citizens via the introduction of new policies to meet Saudi citizens' needs. The department adopted two approaches with which to promote citizen participation and hear and respond to the public's voice. The approaches were social dialogue and the use of digital communication. The objective of this study is to investigate whether the Ministry of Labor allowed foreigners to participate in and engage with other Saudis to meet their interests in terms of employment, education, and other needs to enjoy the life in Saudi Arabia. The theoretical framework adopted for this paper is based on Nico Carpentier's work. Data for the present study were collected through document analyses, in-depth interviews, and focus group discussions. The paper shows that opportunities for foreigners to engage and make their voices heard were given to specific groups. These groups, who hold various types of power, were included with ordinary Saudi citizens in terms of the level of participation given by the Saudi go vernment. These foreigner groups were listened to because they had the power to persuade the Minister of Labor to include them with other Saudis. Additionally, ignoring these powerful foreigner groups could have lead them to act against the Saudis' best interests, which was a main consideration of the Saudi government and Ministry of Labor.
\end{abstract}

Keywords: foreigners, Saudi government, citizen participation, power

\section{Introduction}

From the start of the Arab Spring revolutions, the Saudi government saw the need to respond to the Saudi citizens' needs and provide them with certain benefits that would be in the citizens' best interests (Ministry of Labor, 2016b). However, prior to the Arab Spring revolutions, the Saudi government chose to ignore the citizens' growing discontent. Thus, the Ministry of Labor began to value citizen engagement by identifying and meeting citizen interests (Thompson, 2014). In addition, the Ministry of Labor allowed Saudis to participate in policy creation to meet these needs (Milakovich, 2012; Reddick, 2011).

Thus, Saudi citizens were empowered and allowed to participate in the creation of any policies made by the Ministry of Labor, and the citizens made sure these policies would meet their needs (Ahlerup \& Hansson, 2011). They were able to participate in the decision-making process by attending social dialogues or participating via the Together website and other digital communication methods (Thompson, 2014). However, some foreigners who were born in Saudi Arabia, residents for more than 25 years, and had strong family links with Saudi citizens lacked formal citizenship rights.

It is important to remember that foreigners in Saudi Arabia are divided into two groups: (a) expatriates (contractual foreigners) who live in the country for a brief period of time and then return to their home countries upon the expiration of their employment contracts and (b) foreigners who are part of Saudi society, were born and raised in Saudi Arabia, have acquired Saudi habits and culture, and have helped in the development of Saudi Arabia. There are about two million Saudi foreigners in the country, some of whom are third and fourth generations of families who do not know or belong to any country other than Saudi Arabia (Minister of Labor, 2016). The foreigner community recently launched a Facebook page under the heading, "Born in Saudi Arabia demanding equal treatment like Saudis in labor systems." Al-Oraifi and Al-Oda (2013) stated:

Saudi foreigners share with us a dialect, our clothes, our ideas, our love, our loyalty to Saudi Arabia. If there is a war, they will fight with us. Why do they not deserve the nationality of Saudi Arabia, or equity 
in the Ministry of Labor policies? (para.1)

The objective of the current study is to investigate whether the Ministry of Labor allowed foreigners to participate in and engage with other Saudis in the citizen participation that took place after the Arab Spring uprisings. Did they allow foreigners to vote on the draft agenda published on the Ministry of Labor websites? If yes, why did they allow them to participate, and did they gain any power, similar to the Saudi citizens, that would convince the Ministry of Labor to understand and meet their needs and allow them to participate in any policy from the Ministry of Labor?

\section{Meeting Saudis' Interests}

To satisfy Saudi citizens, in 2012, the Ministry of Labor established a new participatory management department (Ministry of Labor, 2017) that would engage citizens in policy revision and the introduction of any new policies. This was a major step for a country that had been historically dominated by the Saudi monarchy and the country's religious leaders (Ministry of Labor, 2014).

In addition, Saudi citizens became empowered because of the uprisings in some Arab states and the development of social media (Thompson, 2014; Magro, 2012; Swigger, 2013; Sorour \& Lal Dey, 2014; Lorenzi et al., 2014). The power Saudi citizens now hold allows them to participate in the policies developed by the Ministry of Labor. This empowerment has caused the Ministry of Labor to implement a new way of handling the decision-making process, and a shift occurred toward participation by Saudi citizens. Thus, Saudi citizens were informed and consulted to meet their needs, which was a significant transformation. Saudi citizens became informed and were placated when they were consulted.

\section{Social Dialogue}

The Ministry of Labor conducted multiple social dialogues and invited Saudi citizens to attend them. Social dialogue is a way to speed up the process of decision making and resolve disagreements in a transparent manner. This dialogue was a good sign because it indicated that the government and the Ministry of Labor's decisions were not fixed. It also showed that the decisions were not simply the outcome of the government's perceptions, but were also affected by a collaborative agreement with its people. This affect is supported by Cohen (2011) and Thompson (2014), who showed that citizen participation improves policies and decisions by truly reflecting the citizens'needs.

\section{Together Approach and Digital Communication}

The Ministry of Labor utilized digital media and the Together website approach to facilitate public participation, digital communication information, communication technology, and e-government processes have enhanced participatory approaches (Alharbi \& Kang, 2014). The Ministry of Labor implemented digital and social media to strengthen its methods and approaches to governance instead of potentially motivating citizens to revolt against government decisions. In addition, Buhl (2011), Lorenzi et al. (2014), and Alothman (2014) argued that politicians were attempting to respond to the increased influence of social media by using it for their own means, thus using its potential for protest for the government's own agendas instead.

\section{Theoretical Framework}

The literature on citizen participation, including media participation, has produced many distinct positions (e.g., Jenkins and Carpentier (2013) for two recent media-related debates). Arguably, two main approaches to participation can be distinguished in these debates: a sociological approach and a political (studies) approach (Lepik, 2013). The sociological approach defines participation as taking part in particular social processes, a definition that covers a broad area. In contrast, the political approach produces a much more restrictive definition of participation, referring to the equalization of power inequalities in particular decision-making processes (Carpentier, 2011). Participation then becomes defined as the equalization of power relations between privileged and nonprivileged actors in formal or informal decision-making processes. For example, in the field of democratic theory, Pateman's (1970) participation and democratic theory is highly instrumental in showing the significance of power in defining participation, and it is a key illustration of the political approach toward participation. The two definitions of participation that Pateman (1970) introduces are partial and full participation.

Partial participation is defined as a process in which two or more parties influence decisions, but the final power in the decision making rests with one party only (Pateman, 1970; Carpentier, 2013). Full participation is defined as a process where each individual member of a decision-making body has equal power to determine the outcome of the decisions (Pateman, 1970; Carpentier, 2013). Additionally, in the field of urban planning, Arnstein (1969, p. 216) links participation explicitly to power: "... Citizen participation is a categorical term for citize n power."

Within communication studies, attempts have been made to introduce the notion of interaction as an intermediary layer between access and participation (Carpentier, 2016), which concurs with Arnstein's ladder of citizen participation 
(1969). Moving beyond the ladder-based model and without moving outside the political approach, researching participatory processes brings about a series of analytical challenges. If participation refers to the equalization of power relations between privileged and nonprivileged actors, both in formal or informal decision-making processes and within a particular context, then this participation requires these processes (and subprocesses or microprocesses), contexts, actors, decisions, and power relations to be theorized and defined and then analyzed. The number of concepts involved (and invoked) in participatory processes produces a level of analytical complexity that is hard to deal with, especially from a researcher's perspective. Carpentier (2016) developed a four-level and 12-step analytical model that functions within the political approach. In this analytical model, a series of key concepts are used: process, field, actor, decision-making moment, and power. This section will unravel this complexity by developing a four-level analytical model that positions the many different theoretical and analytical concepts, thus acting as a guide for participatory research when applying the political approach..

The questions raised here are as follows: what can each actor generate, and what is generated for them? What is restricted for each actor, and what is restricted by them? Which actions (of which actor) are resisted by which other actor? The structuring question behind this set of questions is as follows: Who decides on what? Once the different power positions of the actors involved in the decision-making moments have been inventoried, these power positions can be compared, paying particular attention to the power positions of privileged and nonprivileged actors. For example, to decide on which guests should be invited to an audience discussion program, one which has a regular panel of ordinary participants, do the media professionals, as a privileged group of actors, decide on this matter, or do they consult or allow the panel of ordinary participants, as a nonprivileged group of actors, to codecide? (see Carpentier [2016] for an extensive discussion of an example called Jan Publiek). Do the ordinary participants resist and attempt to influence this decision, and is their capacity to do so restricted by media professionals?

\section{Methods}

The current research used a qualitative approach that adopted an interpretive, constructionist philosophy. A phenomenological strategy of inquiry was used because it facilitates an understanding of complex phenomena, such as citizen participation, through subjective experiences, in this case, the shared experiences of local ordinary Saudis and Saudi consultants to the Minister of Labor (Rubin \& Rubin, 2011). For these reasons, the phenomenological approach suited the current research.

The data collection technique used was in-depth, face-to-face interviews, focus groups, and document analysis.

\section{Face-to-Face Interviews}

Two procedures were adopted to organize the interviews.

The first procedure was used to organize interviews with Saudis and foreigners. The interview process began with telephone contact to schedule meetings at cafés close to their workplaces or in their homes.

A second procedure was used with personnel from the Ministry of Labor. The researcher visited the ministry to organize interviews and was able to do so without being accompanied by a Muhram (a male relative undertaking a religious role of escort, which is applicable across the country). The Ministry of Labor has a separate department for women, which is located one level down from the men's section; its meetings and conferences are run in the women's department and are attended by both genders. These social and cultural shifts facilitated the researcher's job, and the researcher was able to conduct the interviews with both men and women.

The interviews with Saudi personnel in the Ministry of Labor were arranged with the help of the Academic Affairs, a new department established to support academic research related to the Ministry of Labor's policies and legislation. This department helps academic researchers, provides them with information, figures, and reports, and facilitates meetings with Ministry of Labor staff. The assistant organized meeting times with the consultants and other Saudi high-ranking personnel.

The data were collected by visiting the ministry and organizing the interviews with the participants. For all participants, the interviews continued until information saturation had been reached or until there was sufficient redundancy. All interviews were audio-recorded and later transcribed.

Data collection and sample size. A total of 53 participants took part in the in-depth interviews comprised of 18 high-ranking personnel in the Ministry of Labor (consultants to the Minister of Labor) and 35 foreigners. A snowball sampling method was used, whereby interviewees were asked to give the names of other people with similar characteristics. In addition, LinkedIn, a social networking website for people looking for professional connections, was also used.

Foreigners. The selection criteria for foreigners were the following: born in Saudi Arabia or had worked in Saudi 
Arabia for 25 years or more. This ensured the respondents had integrated into Saudi society and had a sense of belonging to Saudi Arabia.

\section{Interview Topics}

The Ministry of Labor's high-ranking personnel were asked questions such as the following: 'Do you engage foreigners and allow them to participate in introducing and revising Ministry of Labor policies?"; "Why?"; "If yes, what communication tools did you use to engage foreigners in the decision-making process?"; and "How did you experience the foreigner's participation before and during the introduction of policies or revising them?"

The foreigners were asked questions such as the following: "Did you participate in introducing and revising Ministry of Labor policies?"; "Why?"; "What communication tools did you use to participate in the decision-making process?"; "How did you experience the participation model employed by the Ministry of Labor?"; and "Were your contributions considered by the Ministry of Labor?"

Therefore, the current study's approach was the appropriate method for gaining a deeper understanding of subjective experiences and gaining real insights into the lived experiences of the subjects (Rubin \& Rubin, 2011). By using the phenomenological approach, "The study may contribute considerably to inform, support or challenge policy and action" (Lester, 1999, p. 1).

\section{Focus Groups}

The respondents' comfort and homogeneity were assured because each group was interviewed separately, giving them the freedom to talk about what they felt, thought, and perceived in relation to Saudi foreigner's situations in relation to being heard and listened to (Barbour \& Kitzinger, 1999).

Two focus groups were conducted. The first focus group was with foreigners who had lived in Saudi Arabia for more than 25 years. Only five members attended each group discussion. Like the in-depth interviews, the focus group discussions were informal and recorded.

Focus group procedure. The researcher conducted the focus group discussions and interviewed participants after working hours from $6-8 \mathrm{pm}$ in a conference room at the Hilton Hotel, Jeddah. The interviews were conducted away from the participant's formal places of work to allow them to talk freely.

\section{Document Anal ysis}

Documents were selected if they met the following criteria: (a) they were current, that is, the documents had been created no earlier than 2011 and during the Arab Spring revolutions; and (b) the documents explicitly discussed citizen patriation and its implications, along with the situations of foreigners. Having these criteria enabled the researcher to gain an explicit understanding of the reasons, ideology, and objectives underpinning the adoption or prohibition of foreigner participation within the Ministry of Labor.

It is a general practice for social science research studies to retrieve data from documents such as traditional public records, census data, newspaper articles, archives, court documents, government policy documents, di gital documents, and all modes of visual media. Documents can be classified as either primary or secondary sources (Startt \& Sloan, 2003). This research encompassed a review of selected primary and secondary sources. The following were the sources of primary documents collected and analyzed in this study:

- The Ministry of Labor official website and interviews with the Minister of Labor, other involved personnel, and foreigners on YouTube and other media, which provided explanations for the participation and its impact on Saudi society.

- Digital campaigns from the Ministry of Labor website and YouTube videos.

- Published official documents, such as official monthly magazines issued by the Ministry of Labor, the participation guidebook, annual reports, books, and booklets.

- TV programs documented on YouTube, including interviews with sociologists, economists, religious clerics, and experts talking about participation and foreigners and the changes that have occurred in Saudi Arabia since the revolutions in Arab countries.

- Secondary written sources, including current affairs literature and public communication documents such as newspapers. The researcher collected articles from Saudi Dailies online, which encompassed articles from a range of Saudi newspapers; this was done to avoid prejudice by publishers and journalists and to provide a more balanced view of the journalists' positions.

- News found on social media, such as the official Facebook pages for the Ministry of Labor and the minister (Dr. Adel Fakih), the customer service section of the Ministry of Labor (@mol_care), as well 
as tweets from economists and ordinary Saudis who were both for and against participation and foreigners' voices.

Document access procedures. Documents were accessed in many ways. First, during many visits to the Ministry of Labor, the researcher accessed primary documents of the design, progress, and other reports regarding participation and plans for this policy in the future. The Ministry of Labor's official magazine and brochures, as well as handbooks of the Ministry of Labor, were accessed. The researcher was given the government's And Participation Guidebook, proposal, and reports. Third, the researcher also used the Internet to retrieve documents, for example, policy documents uploaded by the Ministry of Labor. As a precaution, the present study followed Yin's (2003) argument that among the key players in a project, the reports, policies, and documents are composed for specific goals. Therefore, understanding the aims and specific goals of documents and the context in which they were produced was crucial for the current research.

\section{Data Analysis}

Analyzing the data collected in this research was conducted through three key steps. First, data were broken down into codes or specific meaningful categories and assigned appropriate labels. Second, the codes were divided into specific themes or categories. Third, the data were displayed, compared, and contrasted. A thematic analysis was used to clearly identify, analyze, and report the patterns found in the data obtained. This particular method allowed the researcher to formulate a clear and concise understanding of the data that could easily be interpreted and analyzed. The following section presents the findings of the themes that emerged from the data analysis.

\section{Results}

\section{Overview}

The findings showed that some foreigners participated in social dialogues and engaged with other Saudi citizens.

Special considerations given to specific foreigner groups. The first theme that emerged from this study was that special consideration is given to specific foreigners that allow them to participate in the introduction and revision of any Ministry of Labor policies. These foreigners, once they have provided proof of their membership to a special group, are registered and treated as Saudis. These groups, who hold various types of power, are treated as ordinary Saudis who have citizen participation.

1 Foreigners who are given special consideration from the Ministry of Labor are divided into five sub-groups in relation to the powers they hold: the first sub-group comprises foreigners who hold power derived from direct relationships with ordinary Saudis; the second comprises foreigners who hold religious power; the third comprises foreigners who hold political power; the fourth comprises foreigners who hold social network power; and the fifth comprises Saudi foreigners with no power.

Foreigners who hold power derived from direct relationships with ordinary Saudis. Eighteen participants (10 high-ranking personnel and eight Saudi foreigners) claimed that the Minister of Labor considered a special group of foreigners, that is, foreign husbands and wives of Saudis and their children. The Ministry of Labor called them special arrivals and considered them to be Saudis. They had direct relationships with ordinary Saudis. The Ministry of Labor personnel who participated in the focus group said that ignoring this group of foreigners would be against Saudi needs because they are important to key members of Saudi families. Consequently, these foreigners have indirect power that causes the Minister of Labor to consider them to be citizens, and this power prevents them from being disadvantaged from having their voices ignored when the Saudi government introduces policies. A high-ranking member of the Ministry of Labor (\#1) said the following:

We are the first Ministry in Saudi Arabia to provide special consideration to foreigners. Considering foreigners who are part of Saudi families was one of our priorities, and this has not happened before and we do our best to protect Saudi families.

Foreigners who hold religious power. Eleven interviewees (six high-ranking personnel and five foreigners) and foreigners who participated in the focus group revealed that the Ministry of Labor also considered other communities, such as the Burmese and Turkestani, ${ }^{1}$ as participants in the introduction and revision of any policies, the same as Saudis. The six high-ranking personnel said that these people had fled from their countries and could not return for religious reasons. They could not practice their religion, and their families were killed because of Islam. Saudi

\footnotetext{
${ }^{1}$ The area known as East Turkistan had been a protectorate of China (Xinjiang) since as early as 60 BCE although it has experienced numerous periods of independence from China. Russian Orthodox old believers emigrated from Russia to Xinjiang in the early 19th century, and the Russian Civil War against Muslims accelerated this immigration by adding white immigrants (Lüthi, 2010).
} 
Arabia is a religious country, and these groups are religious refugees. Therefore, Saudi Arabia should not implicitly expel them from the country by ignoring their needs. It is unreasonable to exclude them now because they were welcomed 50 years ago. Thus, the findings showed that the Minister of Labor had given this group special consideration. This allows Saudi Arabia to retain power, derived from religion, among other Islamic countries.

Five foreigners who were categorized into this group were very appreciative and thankful to the Minister of Labor. They said they were part of this country because they could practice their religion and had jobs as well. Foreigner (\#1) said, "I'm Burmese, and I appreciate the Minister of Labor because he gave Burmese and Turkestani a special consideration and allow us to participate in social dialogue and digital communication to make our voices are accessible to Saudi government."

Foreigners who are political refugees. An analysis of the Ministry of Labor's annual booklet (Ministry of Labor, 2016) emphasized that if Syrians and Palestinians were excluded, it would prove to be a problem for Saudi Arabia because these groups' problems were directly related to political issues and war. These groups are at war, and Saudi Arabia is supportive of those who have fled their countries because of this. The participants said it was right for a religious country such as Saudi Arabia to help and support these groups instead of increasing the pressure on them by ignoring their needs. "Syrians and Palestinians are under war, and it would be a shame for the Saudi government if we allowed them to stay in Saudi Arabia and restricted their needs interests" (Ministry of Labor, 2016a).

Powerless foreigners. This theme discussed how Saudi foreigners are ignored by high-ranking personnel in the Ministry of Labor because of these foreigners' lack of power. As shown in the previous themes, power has a crucial role in the ability to participate with the Ministry of Labor and is included in every decision made regarding policies. From the high-ranking personnel's perspective, foreigners who do not belong to any of the previous groups (who hold political, religious, or social network power) are minorities. Thus, they do not have direct power over the Ministry of Labor to give special consideration and prevent these groups from being affected negatively by any Ministry of Labor policies. Sixteen participants (five ordinary Saudis and 11 foreigners) and foreigners from the focus group stated that the Ministry of Labor did not care about the foreigners' future, even those who had embraced the culture and way of life of the local Saudi people. Rather, the Ministry of Labor chose to ignore them, as expressed in the following quote from ordinary Saudis and Saudi foreigners:

This is a message to the Minister of Labor: please look after foreigners. Provide them with special considerations and stopignoring us. We are Saudis by our hearts and feelings.

Likewise, high-ranking personnel in the Ministry of Labor did not concern themselves with minorities who were not of a Saudi nationality because ignoring them did not conflict with the interests of the Saudi government and the Ministry of Labor. Six out of eight high-ranking personnel claimed that this group numbered only two million, compared to 28 million Saudis, 1.9 million of whom were unemployed and the main interest of the Ministry of Labor. They said citizenship and Saudi nationality were granted based on blood rights (jus sanguinis), and they said it was not fair to consider any foreigners who were born in Saudi Arabia as ordinary Saudis. This was illus trated by the analysis of the Ministry of Labor's reports, as follows:

We are concerned about the 1.9 million unemployed Saudis and we do not care about foreigners who were born and live in Saudi Arabia. It is time to make every Saudi who has Saudi nationality enjoy the benefits of being employed instead of foreigners, no matter whether they are relative foreigners with Saudis or contractual foreigners. (Ministry of Labor, 2016a, p. 3)

'If the Saudi citizenship is not granted, that means the rights of blood (jus sanguinis) are not met. So they don't deserve to be treated as Saudis' (Ministry of Labors member (\#3)),

The fourth theme that emerged was "participatory approach and foreigners," and it examined foreigners who were prohibited from attending social dialogue but who were still allowed to participate in the Together approach.

\section{Participatory Approach and Foreigners}

The Ministry of Labor used a social dialogue approach with which to engage the public sphere, and they invited foreigners who were given special consideration from the Ministry of Labor.

Eleven participants, comprising six high-ranking personnel and five foreigners, said they were invited via an e-mail directly from the Ministry of Labor to attend these dialogues. This was highlighted by a high-ranking member of the Ministry of Labor who said the following:

Social dialogue is beneficial from different aspects, in order to speed up the process of coming out with the right decisions and to indicate that the Ministry of Labor consults ordinary Saudis and so we stop being opinionated in the decisions we make. (Ministry of Labor \#1) 
Eight foreigners said they participated and attended multiple national dialogues. They raised some ideas, and they influenced the final decisions. When the final decision was made and launched, details of the effects that citizens' or foreigners' votes had on the final decision were provided. It was made clear whether the Ministry of Labor followed or ignored the voting results. Therefore, the extent to which Saudi citizens influenced the final decisions after citizen voting was known.

Furthermore, all eight high-ranking personnel from the Ministry of Labor revealed that ultimately, the Ministry of Labor made the final decisions in the creation or amendment of policies. There could not be an entirely bottom-up process, even with the two approaches adopted by for participation. This was emphasized by a Ministry of Labors member (\#2) who said, "Citizens cannot make final decisions, but they can be included in meaningful engagement in this process."

\section{Together and the Use of Digital Communication}

Ten participants (six high-ranking personnel and four foreigners) said that foreigners could visit the Together website (http://www.ma3an.gov.sa) at any time to vote on drafts, decisions, or innovative ideas.

Foreigners' comments on their participation and views about this approach are illustrated by one foreigner's (\#15) comment: "I visited the Together website to vote on the draft of working hours. I'm really in love with this approach, because it's time to make every foreigner's opinion and view accessible to the policy-makers and people in authority."

The high-ranking personnel's comments are illustrated by one member's (\#7) comment: "We keep each party and side separate to ultimately resolve disagreements. Any general consensus or contention is forwarded to Dr. Fakih, the King, and the Shura Committee for finalization."

As discussed previously, the Ministry of Labor considers only a few specific groups of foreigners and ignores the situations of foreigners in certain groups. The foreigners' needs are not an issue for the ruling family and the Ministry of Labor.

In terms of the second participation approach, Together, nine participants (five high-ranking personnel and four foreigners) stated that foreigners, and even foreigners from powerless groups, could vote. They could visit the Together website and vote on drafts of decisions to initiate any ideas that could enhance their future in Saudi Arabia. However, this does not contradict the exclusion of powerless foreigner groups from attending the social dialogues. The high-ranking personnel said the reason for this was that participation via Together is open for everyone who lives in Saudi Arabia. The Ministry of Labor considers this group to be contractual foreigners, and the ministry is not intereste d specifically in the Saudi foreigners' needs in terms of employment and education. However, the ministry is interested in the opinion of all Saudi citizens and foreigners in the country. The high-ranking personnel's views of the foreigners' participation on Together is illustrated in the following quotation:

Foreigners who are not given a special consideration from the Ministry of Labor are prohibited from attending any social dialogues, but still they can participate in any decision-making process by voting on drafts posted in the electronic gate, Together. (Ministry of Labor \#9)

\section{Discussion}

The Ministry of Labor allows foreigners who have been given special consideration to extensively participate in social dialogues so that they can discuss the creation of any policy that could affect their employment in Saudi Arabia. This is supported by White (1999) and Carpentier (2016), who stated that power and control are pivotal for there to be participation through the media. Power and control give foreigners who have been given special consideration the right to communicate and participate in the decision-making process, which is done through national dialogues. However, because the final decisions are made by the Ministry of Labor's high-ranking personnel, the process is not entirely democratic. In addition, the current study found that when final decisions are made and policies launched, details regarding the effect of citizen votes on the outcomes are revealed. Thus, it is made clear whether the Ministry of Labor follows the results of the negotiation process or ignores them. This finding is supported by Pateman (1970) and Carpentier (2016), who stated that in partial participation, two or more parties influence the decisions made, but the power to make a final decision rests with one party only (Pateman, 1970; Carpentier, 2013). In terms of the social dialogues run by the Ministry of Labor, foreigners who attend them influence the decision process, but the decisions are finalized by the high-ranking personnel because they have the most power among the members present at the social dialogues. Thus, foreigners who have been given special consideration by the Ministry of Labor have power, and they attend social dialogues and partially to participate and influence final decisions.

The findings showed that the Ministry of Labor was not concerned about foreigners who have not been given special consideration. These people have no power to persuade the Ministry of Labor to give them special consideration, and they are not allowed to participate as Saudi citizens in making decisions or attending social dialogues. Meeting the needs of foreigners is not an issue for the Ministry of Labor. This finding has been discussed from power and 
participation perspectives.

In terms of power, Carpentier (2016) supported this finding by stating that the power positions of the actors involved in particular decision-making moments can be compared by paying attention to the power positions of the privileged and nonprivileged actors. The power position of powerless foreigners does not provide them the same privileges of ordinary participants; hence, they are a non-privileged group of actors who are excluded from issues in the political agenda. In addition, the power position of the Ministry of Labor excludes these powerless groups from the decision-making process. Thus, the power held by powerless foreigners is valueless when it comes to meeting their interests and engaging in the decision-making process.

The Ministry of Labor has said that it is impossible for powerless foreigners to participate in social dialogue. They are not invited to attend this dialogue though because the Ministry of Labor is not interested in meeting their needs. Therefore, there is a direct and a strong relationship between power and participation.

However, in terms of digital communication and the Together website, foreigners are given special consideration, even powerless foreigners, and they are able to vote and participate. This does not contradict the exclusion of powerless foreigners from contributing to the social dialogue. This is because participation via Together is open to everyone who lives in Saudi Arabia. Although the Ministry of Labor is not interested in the specific needs of these cohorts, it is interested in the opinion of all Saudis and foreigners in the country.

In conclusion, the powers held by some Saudi foreigners have persuaded the Ministry of Labor to consider them as Saudi citizens, at least to some extent. These powers are sufficient enough to allow these groups to participate in decision making via social dialogues. However, the Ministry of Labor does not concern itself with meeting the needs and interests of foreigners.

\section{References}

Ahlerup, P., \& Hansson, G. (2011). Nationalism and government effectiveness. Journal of Comparative Economics, 39(3), 431-451. https://doi.org/10.1016/j.jce.2011.05.001

Alharbi, A., \& Kang, K. (2014). E-participation service in Saudi Arabian e-government websites: The influencing factors from citizens' perspective. In Proceedings of the 14th European Conference on e-Government: ECEG 2014 (pp. 265-272).

Al-Oraifi, M., \& Al-Oda, S. (2013, 18 April). Born in Saudi Arabia demanding equality treatment like Saudis in labor systems. Retrieved from http://www.facebook.com/Born.in.Saudi.Arabia.

Alothman, A. B. (2014). Asurvey of social media users in Saudi Arabia to explore the roles, motivations and expectations toward using social media for social and political purposes (Masters Dissertation, Arkansas State University, Jonesboro, US).

Arnstein, S. R. (1969). A ladder of citizen participation. Journal of the American Planning Association, 35(4), 216-224. https://doi.org/10.1080/01944366908977225

Barbour, R., \& Kitzinger, J. (1999). Developing focus group research: Politics, theory and practice. London, UK: Sage. https://doi.org/10.4135/9781849208857

Buhl, H. U. (2011). From revolution to participation: Social media and the democratic decision-making process. Business \& Information Systems Engineering, 3(4), 195-198. https://doi.org/10.1007/s12599-011-0166-4

Carpentier, N. (2011). Media and participation: A site of ideological-democratic struggle. Bristol, UK: Intellect. https://doi.org/10.26530/OAPEN_606390

Carpentier, N. (2013). The identity constructions of media professionals. Coping with modernist articulations of the media professional as author and the recognition of difference. In S. Mertens (Ed.), Perspectievenop internationale journalistiek [Perspectives on International Journalism] (pp. 5-18). Gent, Belgium: Academia Press.

Carpentier, N. (2016). Beyond the ladder of participation: An analytical toolkit for the critical analysis of participatory media processes. Javnost-The Public, 23(1), 70-88. https://doi.org/10.1080/13183222.2016.1149760

Cohen, N. (2011). Citizen participation. Thousand Oaks, CA: Sage.

Jenkins, H., \& Carpentier, N. (2013). Theorizing participatory intensities: Aconversation about participation and politics. Convergence, 19(3), 265-286. https://doi.org/10.1177/1354856513482090

Lepik, K. (2013). Governmentality and cultural participation in Estonian public knowledge institutions (Doctoral dissertation). Retrieved from ProQuest Dissertations and Thesis database.

Lester, S. (1999). An introduction to phenomenological research. Taunton, UK: Stan Lester Developments. 
Lorenzi, D., Vaidya, J., Shafiq, B., Chun, S., Vegesna, N., Alzamil, Z., \& Atluri, V. (2014, June). Utilizing social media to improve local government responsiveness. Paper presented at the Proceedings of the 15th Annual International Conference on Digital Government Research, Aguascalientes, Mexico. https://doi.org/10.1145/2612733.2612773

Lüthi, L. (2010). The Sino-Soviet Split: Cold War in the Communist World. Princeton: Princeton University Press. https://doi.org/10.1515/9781400837625

Magro, M. J. (2012). A review of social media use in e-government. Administrative Sciences, 2(2), 148-161. https://doi.org/10.3390/admsci2020148

Milakovich, M. E. (2012). Digital governance: New technologies for improving public service and participation. New York, NY: Rutledge.

Minister of Labor. (2016, December 13). Employment policies/interviewers: Abdullah Al-Mudaifer [video file]. Retrieved from https://www.youtube.com/watch?v=hm-YJ7XiKNs.

Ministry of Education. (2016). Final decisions. Retrieved from https://www.moe.gov.sa//Memos/gr.pdf

Ministry of Labor. (2016a). Annual report. Riyadh, Saudi Arabia: Author.

Ministry of Labor. (2016b). The power of social media. Riyadh, Saudi Arabia: Author.

Ministry of Labor. (2017). Achievement and challenges in 2016 Report. Saudi Arabia: Author.

Pateman, C. (1970). Participation and democratic theory. Cambridge, UK: Cambridge University Press. https://doi.org/10.1017/CBO9780511720444

Reddick, C. G. (2011). Citizen interaction and e-government. Transforming Government: People, Process and Policy, 5(2), 167. https://doi.org/10.1108/17506161111131195

Rubin, I. S., \& Rubin, H. J. (2011). Qualitative interviewing: The art of hearing data. Thousand Oaks, CA: Sage.

Sorour, M. K., \& Lal Dey, B. (2014). Energising the political movements in developing countries: The role of social media. Capital \& Class, 38(3), 508-515. https://doi.org/10.1177/0309816814550390

Swigger, N. (2013). The online citizen: Is social media changing citizen beliefs about democratic values? Political Behavior, 35(3), 589-603. https://doi.org/10.1007/s11109-012-9208-y

Thompson, M. (2014). Saudi Arabia and the path to political change: National dialogue and civil society. New York, NY: IB Tauris \& Co Ltd.

White, R. (1994). Participatory development communication as a social-cultural process. In S. A. White, K. S. Nair, \& J. Ascroft (Eds.), Participatory communication: Working for change and development (pp. 49-59). New Delhi, India: Sage.

Yin, R. K. (2003). Case study research: Design and methods. (4th ed.). London, UK: Sage.

\section{Copyrights}

Copyright for this article is retained by the author(s), with first publication rights granted to the journal.

This is an open-access article distributed under the terms and conditions of the Creative Commons Attribution license which permits unrestricted use, distribution, and reproduction in any medium, provided the original work is properly cited. 